\title{
BHATTARA NARAPATI
}

\author{
Oleh: Soeroso Mp.
}

\section{PENDAHULUAN}

Sejarah Majapahit setelah meninggalnya raja Hayam Wuruk sekitar tahun 1389, diwarnai dengan bermacam-macam peristiwa pertikaian di kalangan keluarga kerajaan. Pertikaian tersebut bersumber pada masalah perebutan tahta pemerintahan di antara para penguasa daerah (raja vassal) yang sebagian besar merupakan kerabat raja. Pertikaian ini mencapai puncaknya pada masa pemerintahan raja Wikramawardhana alias Bhre Hyang Wicesa melawan Bhre Wira. bhumi. Peperangan yang lazim disebut dengan nama perang Paregreg berakhir dengan hancurnya keraton timur serta terbunuhnya Bhre Wirabhumi pada tahun 1406 M. (Pararaton: 31, 5-15, Groeneveldt: 37). Kejadian ini ternyata belum mengakhiri pertikaian yang telah berlangsung lama tersebut karena pada tahun $1433 \mathrm{M}$, Bhre Narapati juga dibunuh atas tuduhan telah menghilangkan nyawá Bhre Wirabhumi. Banyaknya pertentangan dan peperangan ternyata makin memperlemah kewibawaan kerajaan Majapahit. Akhirnya pada tahun 1489 - 1513-an kerajaan ini mendapat serangan dari kerajaan Daha yang ternyata juga merupakan keluarga Majapahit. Serangan ini berakibat pindahnya pusat pemerintahan Majapahit ke Daha. meskipun tidak secara keseluruhan. (Noorduyn 1978: 271).

Di antara sekian banyak tokoh yang terlibat di dalam persengketaan tersebut di muka maka yang menarik perhatian ialah tampilnya tokoh Bhra Narapati. Baik di dalam prasasti masa itu maupun di dalam kitab Pararaton dan Negarakertagama sangat sedikit menyebut mengenai tokoh ini. Akan tetapi ternyata Bhra Narapati merupakan tokoh yang penting di dalam perang Paregreg karena dialah yang berhasil membunuh Bhre Wirabhumi. Demikian juga melihat 
jabatan yang dipegangnya yaitu sebagai patih Daha sekaligus sebagai Angabhaya serta gelar yang disandangnya yaitu Bhra, memberikan kesan bahwa dia adalah keluarga raja. Oleh karenanya tidak aneh bila dia sangat berperan di dalam peperangan antara Bhre Wirabhumi dan Wikramawarddhana. Usaha yang dilakukan dengan membunuh Bhre Wirabhumi mungkin berambisi untuk menggantikan kedudukan Bhre Wirabhumi . Akan tetapi usaha-usahanya itu ternyata gagal karena akhirnya ia sendiri juga dibunuh.

\section{SUMBER TENTANG BHRA NARAPATI}

Di dalam Páraraton disebutkanbahwa akibat perang Paregreg pada tahun 1406 ialah hancurnya kerajaan timur serta tewasnya Bhre Wirabhumi. Disebutkan di sini bahwa:

Kalah kedaton wetan. Bhre Daha ingěmban denira bhra Hyang Wiçesa bhinakta mangilen. Bhra Wirabhumi lungha ring wěngi, tumulumpak ing parahu, tinut denira raden Gajah bhiseka ratu angabhaya, bhra Narapati. Katututan ing parahu, minoktan tur pinok bhinakta datěng ing Majapahit, dhinarma ta sira ring Lung, dharmmabhiseka ring Goriçapura i çaka duk parěgrěg agung naga-laranahut-wulan 1328. (Pararaton: 31. 10-15).

Yang artinya kurang lebih demikian:

Kerajaan timur dikalahkan. Bhre Daha diboyong oleh bhra Hyang Wiçesa dibawa ke kedaton barat. Bhra Wirabhumi pada malam hari pergi dengan naik perahu, dikejar oleh Raden Gajah atau ratu angabhaya yang bergelar bhra Narapati. la tertangkap selanjutnya dibunuh dan kepalanya dipenggal dibawa ke Majapahit, didarmakan di Lung di Goriçapura nama candi pendarmaannya, perang besar parěgrěg itu berlangsung pada tahun çaka naga-laranahut-wulan 1328.

Akan tetapi rupa-rupanya perbuatan Bhra Narapati ini berakibat pula bagi dirinya. Pada tahun 1433 dia sendiri juga dibunuh atas tuduhan telah menghilangkan nyawaj̉Bhre Wirabhumi. Peristiwa peperangan ini tampaknya sangat terkenal di dalam roman Jawa sehingga terdapat ceritera Roman tentang Minak Jinggo - Damarwulan. Isi pokoknya ialah peperangan antara Damarwulan (Bhra Narapati) melawan Minak Jinggo alias Urubhisma (Wirabhumi) penguasa kerajaan Blambangan. Akhir ceritera Minak Jinggo dapat dibunuh oleh Damarwulan dan kepalanya dibawa ke Majapahit. Sumber lain yang menyebut tentang peperangań pitu dapat ditemukan di dalam berita Cina yang menyebut- 
kan tentang peperangan antara keraton barat dan keraton timur. Peperangan ini berakhir dengan kekalahan di fihak keraton timur serta rajanya ikut terbunuh. Bahkan dapat diketahui pada saat terjadi perang itu, sekitar 170 orang Cina tewas. (Groeneveldt: ibid). Akan tetapi sayang di dalam keterangan ini tidak disinggung sedikitpun mengenai tokoh bhra Narapati. Sumber lainnya tentang bhra Narapati ditemukan di dalam kitab Nagarakrtagama pupuh 12. Di sini disebutkan sebagai berikut:

nkakeng uttara lor sakeng pkěn agěng kuwwu ahalp/çobhita, sang saksat ari de nareçwara ri wěngkěr sang makuww apagöh, satyasih ri narendradira nipuněng nityapatih ring daha, kyating rat/mangaran/bhattara narapaty ande halp ning praja. (Nagarakrtagama 12, 3a-d).

Yang artinya kurang lebih sebagai berikut:

Di sebelah utara, utara pasar, terletak rumah bagus dan anggun. di situlah menetap patih daha, yang bagaikan adik baginda Wengker,

Sangat setia, taat kepada raja. ulet dan ahli dalam tata pemerintahan. yang termasyur dengan gelar bhattara Narapati, sangat tangkas dan bijak. sana.

Dari keterangan tersebut di atas jelas bila Bhra Narapati ialah patih kerajaan (otonom) Daha, yang dianggap sebagai/bagaikan adik bhre Wěngkěr dan juga yang menjabat sebagai ratu angabhaya. Oleh karenanya tidak aneh bila kedudukannya sebagai patih di Daha, sebagai ratu angabhaya di Majapahit dan yang bergelar bhra itu mempunyai peranan yang sangat penting pada masa itu. Demikian juga mengenai kedudukannya sebagai patih di Daha rupa-rupanya juga merupakan kedudukan yang tinggi karena apabila dilihat dalam sistim pemerintahan masa itu.ternyata banyak raja atau patih yang sebelum menduduki jabatan di Majapahit terlebih dahulu harus menjadi patih atau raja muda di Daha. Demikian pula halnya dengan kedudukannya sebagai ratu angabhaya. ternyata gelar/kedudukan semacam itu dipegang oleh orang yang mempunyai hubungan dekat dengan raja. Sebagai contoh misalnya "Tumuli sira Rangga Wuni angadeg ratu, Kadi naga roro saleng lawan sira Mahisa Campaka. Sira Rangga Wuni abhiseka Wisnuwarddhana karatunira, sira Mahisa Campaka dadi ratu angabhaya abhiseka bhattara Narasinga". (Pararaton 18, 5-10). Di sini tampak bahwa hubungan antara Ranggawuni dengan Mahisa Campaka ternyata dekat sekali yaitu saudara satu nenek (Ken Dedes) tetapi lain kakek. Ranggawuni cucu Tunggul Ametung sedangkan Mahisa Campaka cucu Ken Arok. Apabila 
hubungan ini juga berlaku bagi Bhra Narapati dengan Bhre Wengker, maka mungkinkah Bhra Narapati itu juga saudara dengan Bhre Wengker. Lalu apakah motivasi pembunuhan atas Bhre Wirabhumi itu?

\section{PENAFSIRAN TENTANG BHRA NARAPATI}

Bersumber dari dua buah kitab yaitu Pararaton dan Nagarakrtagama untuk memecahkan masalah identifikasi seorang tokoh seperti Bhra Narapati memang sangat sulit. Lebih-lebih lagi tokoh tersebut sangat sedikit disebut dalam sejarah pada masa itu. Akan tetapi mengingat peranannya pada masa Majapahit terutama saat timbulnya peransParegreg maka dapat diduga bahwa kedudukannya di dalam pemerintahan dan keluarga Majapahit sangat penting.

Seperti disebut di dalam Nagarakrtagama bahwa hubungan antara Bhra Narapati dengan Bhre Wengker alias Wijayarajasa yaitu pamanda Hayam Wuruk dinyatakan dengan istilah sang saksat ari. Pigeaud menterjemahkan kalimat tersebut "the honoured one who manifestly is younger brother to the Prince in Wengker", sedangkan Slamet Muljana menteriemahkan dengan "adinda baginda di wengker". (Pigeaud: III, 12, 3b; Slamet Muljana!1979: 279 pupuh 12,3b). Penggunaan istilah sang saksat di sini lebih mendekatkan fikiran kita pada pe. ngertian bagaikan atau ibarat. Dengan demikian Bhre Narapati itu rupa-rupanya bukanlah adik kandung melainkan adik dalam pengertian adik sepupu atau adik misan atau adik tiri dan lain sebagainya. Mengingat bahwa gelar Bhra atau Bhre atau Bhattara itu adalah gelar kehormatan sekaligus gelar jabatan para keluarga raja Majapahit, maka dapat dikatakan bila Bhra Narapati adalah keluarga raja. Lebih lanjut Pigeaud juga telah menunjukkan tentang kedudukan yang tinggi dari Bhra Narapati dibandingkan dengan kedudukan Gajah Mada sendiri. (Pigeaud: Vol. IV. 12, 3-4). Jabatan mantri adalah gelar yang lebih rendah dan tidak untuk seseorang pangeran seperti bhattara Narapati. Lebih lanjut dapat diketahui bahwa kedudukan bhattara Narapati atau ratu angabhaya Narapati menurut Nagarakrtagama ialah di sebelah utara pěkěn agěng atau pasar besar. Kedudukan semacam ini mengingatkan kita pada gelar yang disandang oleh putera Kyai Agěng Pemanahan yang bernama Raden Bagus, alias Sutawijaya. Ia diambil sebagai anak angkat oleh prabhu Hadiwijaya di Pajang yang akhirnya bergelar mas-ngabehi-loring-pasar (Babad Tanah Djawi: 49). Lebih lanjut Maclaine Pont pernah menunjukkan bahwa apabila denah kweron Majapahit itu mirip dengan keraton Jogya atau Solo maka lokasi 
tempat tinggal Ngabehi-Loring-Pasar itu letaknya di sebelah utara pasar. (Maclaine Pont 1924: 15). Dengan demikian terdapat kesan bahwa bhra Narapati yang kedudukannya di sebelah utara pěkěn agěng itu sama juga dengan Ngabehi Loring Pasar pada masa Mataram Islam.

Berdasarkan uraian tersebut di muka dapatlah sekarang dirumuskan sebagai berikut:

1. Bhra Narapati adalah tokoh yang bagaikan adik Bhre Wengker. la bukan adik kandung tetapi dari garis lain misal adik sepupu dan lain-läininìyâ.

2. Ia adalah patih Daha sekaligus sebagai ratu angabhaya. Dengan demikian ia menduduki jabatan yang penting dan lebih terhormat dibanding Gajah Mada.

3. Sebagai Ngabehi Loring Pasar, ia sangat tahu tentang seluk beluk dan peris tiwa yang terjadi di dalam lingkungan kraton pada masa itu. Oleh karena. nya tidak mengherankan seandainya ia juga berambisi untuk memperoleh kedudukan yang lebih tinggi.

Seperti telah disebutkan di muka bahwa perang Paregreg yang melibatkan Wikramawarddhana dan Bhre Wirabhumi itu ialah perebutan kekuasaan. Dapat diketahui bahwa Wikramawarddhana naik tahta menjadi penguasa Majapahit sebenarnya karena perkawinannya dengan Kusumawarddhani (puteri mahkota). Di lain fihak Bhre Wirabhumi adalah putera Hayam Wuruk dengan binihaji (rabianom), sekaligus iã juga diangkat sebagai putera Bhre Daha (Daha II atau Bhre Lasem I) atau Rajasaduhitendudewi atau W̉arddhanaduhiteswiari (Norduyn 1968: 542-544). Bhre Daha ke II ini adalah puteri Wijayarajasa (Bhre Wengker) hasil perkawinannya dengan Rajadewi. Dengan demikian dapat diketahui bahwa hubungan antara Wikramawarddhana berdasarkan garis ke turunan dari fihak ibu dengan Bhre Wirabhumi dari garis keturunan ayah adalah satu nenek yaitu Rajapatni. Demikian juga hubungan antara Kusuma. wardhani dengan Bhre Wirabhumi berdasarkan garis keturunan ayah adalah satu nenek ialah Rajapatni. Oleh, karena| dari garis keturunan ayah, maka Wirabhumi menganggap lebih berhak atas tahta pemerintahan. Rupa-rupanya pertentangan antara Wikramawarddhana dengan Bhre .Wirabhumi ini sudah tidak dapat dihindari lagi sehingga terjadilah perang, Plaregreg sejak tahun 1323 C sampai dengan 1328 C. Dalam peperangan itu pertama kedaton barat menderita kekalahan akan tetapi setelah dibantu oleh Paduka Parameçwa- 
ra (Bhre Tumapel) kedaton wetan dapat dihancurkan. Dengan kekalahan kedaton wetan tersebut akhirnya Bhre Daha diboyong ke kedaton kulon.

Rupa-rupanya peristiwa kemelut yang terjadi sejak meninggalnya Hayam Wuruk hingga pecahnya perang Paregreglitu tidak hanya melibatkan Wikrama. warddhana dan Bhre Wengker saja,tetapi juga dimanfaatkan oleh fihak ketiga. Kedudukan Bhra Narapati sebagai yang sudah disebutkan di muka ternyata mempunyai peluang untuk memenuhi tuntutannya. Sebagai orang yang tahu betul suasana di dalam lingkungan istana, terlebih tentang hubungan antara Bhre Wirabhumi dengan Bhre Daha, maka kesempatan itu dimanfaatkan. Bhre Wirabhumi disingkirkan sehingga ia dapat menggantikan kedudukannya. Akan tetapi rupa-rupanya ia salah perhitungan karena yang menggantikan menjadi raja setelah Wikramawarddhana meninggal adalah Suhita (1429 - 1477). Dapat diketahui pula bahwa Suhita ialah puteri Wikramawarddhana dari perkawinan nya dengan seseorang yang belum diketahui. Rupa-rupanya peristiwa pembu nuhan atas diri Bhre Narapati yang dicatat di dalam Pararaton "Raden Gadjah ingilangakěn pinidosa ameki bhre Wirabhumi" pada tahun Çaka 1355, ada kait annya dengan identitas ibu Suhita. la adalah mungkin puteri atau salah satu puteri Wirabhumi. (Krom 1931;446: Soekmono 1961: 71). Dengan demikian kemungkinan besar bahwa kemelut yang terjadi antara Bhre Wirabhumi dengan Wikramawarddhana itu tidak hanya karena benih yang telah lama ada tetapi juga karena hasutan fihak ketiga yang sedikit banyak ingin menggunakan ke sempatan itu untuk memperoleh kedudukan yang lebih tinggi. Akan tetapi se belum usaha yang dirintis tersebut memperoleh hasil ia sendiri diganyang hingga akar-akarnya.

\section{KESIMPULAN}

Berdasarkan uraian tersebut di muka jelaslah bahwa Bhra Narapati yang men jabat sebagai patih di Daha yang bergetar pula sebagai ratu angabhaya ter nyata adalah juga masih keluarga raja. Kedudukannya yang tinggi serta status sosialnya yang tinggi pula memungkinkan ia untuk mencapai/menuntut kedu dukan yang lebih tinggi kendatipun hal itu adalahbukan haknya. Usaha untuk memperoleh kedudukan tersebut dilaksanakan dengan cara mengobarkan benih pertentangan antara Wikramawarddhana dengan Bhre Wirabhumi. Dalam ke sempatan itu ia berhasil menyingkirkan Bhre Wirabhumi lawan utamanya de ngan tujuan untuk dapat menguasai Bhre Daha. Akan tetapi belum lagi dapat mengenyam hasil jerih payahnya itu rupa-rupanya niat jahatnya diketahui sehingga ia sendiri juga mengalami nasib yang sama. 


\section{DAFTAR BACAAN}

Brandes J.L.A., 1897. "Pararaton (Ken Arok) of het boek der Koningen van Tumapel en van AAajapahit", V.B.G. XLIX. Batavia, Albrecht \& Co, ’sGravenhage; AAartinus Nijhoff.

Groeneveldt, W.P. 1880. "Notes on the AAalay Archipelago and AAalacca Compiled from Chinese Sources", V.B.G. XXXIX, Batavia, Albrecht \& Co, 'sGravenhage; AAartinus Nijhoff.

Hasan Djafar, 1978. Girindrawarddhana Beberapa AAasalah AAajapahit Akhir, Jakarta: Yayasan Dana Pendidikan Buddhis Nalanda.

Krom, N.J. 1930. Hindoe-Javaansche Geschiedenis. Tweede herziene druk 'sGravenhage; AAartinus Nijhoff.

AAaclaine Pont, 1924. "AAajapahit. Paging tot-Reconstructie van het Stadsplan, nagezocht op het terrein aan de hand van den

AAiddeleeuwenschen Dichter: Prapanca ", D.V., Bijlage D Hal. 36- 75; Bijlage Q hal. 157 - 199, Weltevreden; Albrecht \& Co, 's-Gravenhage, AAartinus Nijhoff:

Noorduyn, J., 1968. "The Names of Hayam Wuruk's Sisters", B.K.I. 124, hal. 542 - 544, Leiden: 's-Gravenhage, AAartinus Nijhoff.

Noorduyn, J., 1978 "AAajapahit in the Fifteenth Century", B.K.I. 134, Leiden: 's-Gravenhage, AAartinus Nijhoff.

Dlthof, W.L., 1941. Poenika Serat Babad Tanah Djawi wiwit saking Nabi Adam doemoegi ing tahun 1647. 's-Gravenhage, AAartinus Nijhoff 2 Jilid.

Pigeaud, TH.G.TH., 1960. Java in the 14th Century: A Study in Cultural History. The Nagarakrtagama by Rakawi Prapanca of AAajapahit, $1365 \mathrm{AD}$. The Hague: AAartinus Nijhoff, Vol. I - VI. 
Slamet Muljana Slamet Muljana, 1979. Nagarakrtagama dan Tafsir Sejarahnya, Jakarta: Bhratara Karya Aksara.

Soekmono, R., 1960. Pengantar Sejarah Kebudayaan Indonesia II. Jakarta: Trikarya, cetakan ketiga. 